\title{
Virulence of Egyptian Blumeria graminis f. sp. tritici Population and Response of Egyptian Wheat Cultivars
}

Abdelrazek Abdelrhim, Harby M. Abd-Alla, El-Sayed Abdou, and Mamdoh E. Ismail, Department of Plant Pathology, Minia University, Egypt; and Christina Cowger, ${ }^{\dagger}$ Agricultural Research Service, Raleigh, NC; and Department of Entomology \& Plant Pathology, North Carolina State University, Raleigh 27695

\begin{abstract}
Powdery mildew, caused by Blumeria graminis (DC.) Speer f. sp. tritici (Em. Marchal), is a serious disease of wheat that can cause a large reduction in yield. In Egypt, high powdery mildew severity has been observed in the past few years on many commercial cultivars of both bread and durum wheat. Little information is available about virulence characteristics of the Egyptian B. graminis f. sp. tritici population in Egypt or the resistance of Egyptian wheat cultivars to powdery mildew. Virulence frequencies of a representative sample of the Egyptian B. graminis f. sp. tritici population were studied. Seven provinces were chosen to represent the country: two in Upper Egypt (Qena and Sohag), one in Middle Egypt (El Minia), and four in the north (Alexandria, Kafr Elsheikh, Dakahlia, and Sharqia). Ten isolates from each province (70 isolates total) were derived from single ascospores and used for this study. They were inoculated individually

on 21 powdery mildew differential lines, each bearing a single resistance $(P m)$ gene. Also, the responses of 14 Egyptian bread wheat cultivars and 6 durum cultivars to each of the 70 isolates were evaluated individually. Among all tested $P m$ genes, only seven $(P m 1 b, P m 2$, Pm21, Pm34, Pm36, Pm37, and Pm53) were effective against B. graminis f. sp. tritici isolates from all provinces. Several other genes were effective against most or all isolates from a majority of provinces. All tested bread wheat cultivars showed full susceptibility to all isolates, whereas two durum wheat cultivars, Beni-Suef-5 and Beni-Suef-6, had intermediate responses to a large percentage of the isolates, likely indicating partial resistance. To enhance mildew resistance in Egyptian wheat cultivars, it is recommended to use combinations of genes that are nationally effective or effective against multiple provincial $B$. graminis f. sp. tritici populations.
\end{abstract}

In the Mediterranean region and North Africa, bread wheat is one of the most important cereal crops. Durum wheat, with its multiple food uses, is also essential throughout the Mediterranean region, which accounts for about $60 \%$ of world durum production (Abad et al. 2004). In Egypt, wheat is an important staple food, with an annual consumption of about 12.4 million tons, of which about 9.4 million tons are grown locally (Rashed et al. 2016) on 1,428,000 ha; about $90 \%$ of that is bread wheat and $10 \%$ is durum wheat.

Wheat powdery mildew, caused by Blumeria graminis (DC.) Speer f. sp. tritici (Em. Marchal), can cause severe damage to wheat in various parts of the world. B. graminis f. sp. tritici is an obligate and host-specific fungal pathogen that colonizes wheat leaves, stem, and spikes and produces a white to gray cottony growth on upper leaf surfaces. When environmental conditions are favorable, powdery mildew may cause partial to total yield loss on susceptible cultivars (Zhang et al. 2015). The disease reduces photosynthesis, increases respiration, reduces root growth, and impedes grain-fill in heavily infected spikes (Akhkha et al. 2003; Last 1962; Sabri et al. 1997). Also, early-season wheat powdery mildew epidemics reduce the number of tillers and the number of kernels per head (Jevtic et al. 1991).

B. graminis f. sp. tritici subsists between seasons as chasmothecia (sexual fruiting bodies), which constitute the primary inoculum for the following season (Götz et al. 1996). Ascospores are generally assumed to be released during autumn but that may vary due to weather and environmental conditions (Smedegard-Petersen 1967; Turner 1956) .

Although Egyptian researchers and wheat breeders focus largely on breeding for rust resistance, yield, and quality, powdery mildew

${ }^{\dagger}$ Corresponding author: C. Cowger; E-mail: Christina.Cowger@ars.usda.gov

The United States Department of Agriculture is an equal opportunity provider and employer.

Accepted for publication 12 September 2017.

This article is in the public domain and not copyrightable. It may be freely reprinted with customary crediting of the source. The American Phytopathological Society, 2018. can be a significant problem in Egyptian wheat crops grown under higher moisture and fertility conditions. Wheat powdery mildew can spread rapidly in Egypt, given mild temperatures and high humidity during February and March (El-Shamy et al. 2012). Egyptian losses in wheat yield due to powdery mildew may reach 10 to $18 \%$ (El-Shamy et al. 2012).

The two principal ways to control wheat powdery mildew are fungicides and cultivars that possess quantitative resistance or major resistance (Pm) genes (Leath and Bowen 1989; Leath and Heun 1990; Niewoehner and Leath 1998). As of recently, there were approximately 77 identified alleles at 49 loci conferring resistance to wheat powdery mildew (Hao et al. 2015). In Egypt, the majority of wheat is grown in small fields ( $<1$ ha to several hectares), with each field having a different owner, which reduces fungicide application efficiency. Hence, using resistant cultivars has important advantages for controlling wheat powdery mildew in Egypt.

However, B. graminis f. sp. tritici has the ability to rapidly overcome resistance genes due to high mutation rates, regular sexual reproduction, and huge effective population sizes. In order to respond to this problem, there is a need for different types of genetic resistance with greater durability (Peusha et al. 2000; Szunics and Szunics 1999), as well as new resistance sources. Wheat breeders use virulence data from mildew population surveys to identify $P m$ genes that may be useful for their breeding programs (Limpert et al. 1987; Niewoehner and Leath 1998).

In Egypt, there have been only two studies involving wheat powdery mildew. One was conducted by El-Shamy et al. (2016), who determined the virulence of $B$. graminis $\mathrm{f}$. $\mathrm{sp}$. tritici isolates collected from the north of Egypt. These authors reported high susceptibility of all tested Egyptian cultivars to all B. graminis f. sp. tritici isolates. The other study was carried out by Emara et al. (2016), who used four simple-sequence repeat markers to detect $P m$ genes in 13 Egyptian cultivars; they concluded that Pm24, Pm35, and Pm37 were absent in all the tested cultivars.

More information is required about wheat powdery mildew in Egypt, with respect to both the pathogen population and the resistance available in widely used germplasm. The present investigation aimed to (i) develop a more comprehensive picture of variability for virulence in the B. graminis f. sp. tritici population across Egyptian 
wheat-growing areas and (ii) evaluate representative Egyptian bread and durum wheat cultivars for their responses to different $B$. graminis f. sp. tritici isolates.

\section{Materials and Methods}

Sampling of Egyptian B. graminis f. sp. tritici population. Seventy samples of powdery mildew-infected wheat leaves bearing chasmothecia of $B$. graminis $\mathrm{f}$. sp. tritic $i$ were collected from wheat fields in seven provinces in Egypt during the 2015-16 growing season (Fig. 1). Infected leaf samples were placed in paper envelopes and sent to Raleigh, NC for derivation of isolates and identification of virulence profiles.

Ascospore ejection and derivation of isolates. The following protocol was used for chasmothecial maturation and ascospore ejection. Filter paper (Whatman International Ltd., Madistone, England) with an 11-cm diameter was cut into strips $2 \mathrm{~cm}$ wide, such that a single strip, when pressed into the lid of a small Petri plate (60 by $15 \mathrm{~mm}$ ), extended out from the lid about $1 \mathrm{~cm}$ in each direction. The small Petri plate was then placed in a large Petri plate (100 by $15 \mathrm{~mm}$ ) containing sterilized water, so that the paper strip ends touched the water and remained moist.

A 2- to 3-cm segment of the infected leaf sample was dipped in $1 \%$ bleach ( $8.25 \%$ sodium hypochlorite) for $1 \mathrm{~s}$ and rinsed in deionized water. The noninfected side of the leaf was placed on the filter paper strip in the small Petri plate lid, where it adhered due to the moisture, and then the lid with the leaf segment was replaced on its plate in the larger plate of water. The large plate was transferred to a clear plastic box with a hinged lid, with six large plates per box, and incubated at approximately $17.3^{\circ} \mathrm{C}$ on a 12-h cycle of light and darkness.

After 7 days, leaf pieces from 10-day-old seedlings of the susceptible wheat cultivar Jagalene (PVP 200200160) were floated on small plates of $0.5 \%$ water agar amended with benzimidazole at $50 \mathrm{mg} /$ liter. The lids with the chasmothecia-bearing leaves were placed on the plates containing the Jagalene leaf pieces and incubated at 17 to $18^{\circ} \mathrm{C}$ with $12 \mathrm{~h}$ of light for $24 \mathrm{~h}$. Then, the plates of Jagalene leaf segments were removed, covered with plain lids, and incubated in a growth chamber (approximately $17^{\circ} \mathrm{C}, 12 \mathrm{~h}$ of light) for 10 days, until pustules appeared.

As soon as individual pustules were visible, conidia were transferred with a dissecting needle from a single colony onto a fresh leaf piece on a benzimidazole/water agar plate, and incubated in a growth chamber (approximately $17^{\circ} \mathrm{C}, 12 \mathrm{~h}$ of light) for 10 days. A second round of subculturing was conducted under the same conditions in order to obtain a pure culture. The cultures obtained from each pustule were subsequently increased for further studies.

Characterization of isolates. In order to analyze virulence, each pure isolate was inoculated on a set of 21 wheat differential lines, each with a single $P m$ gene, plus Jagalene as a susceptible control (Table 1). Some of the genes have long been in use in commercial cultivars, and some were recently introgressed into a common wheat background. One (Pm36) was in a durum wheat line.

Experimental units for inoculation were individual Petri plates containing all differential lines and susceptible controls. For replication, all differential plates contained two detached leaves of each differential line; i.e., each plate contained 21 differentials plus the controls.

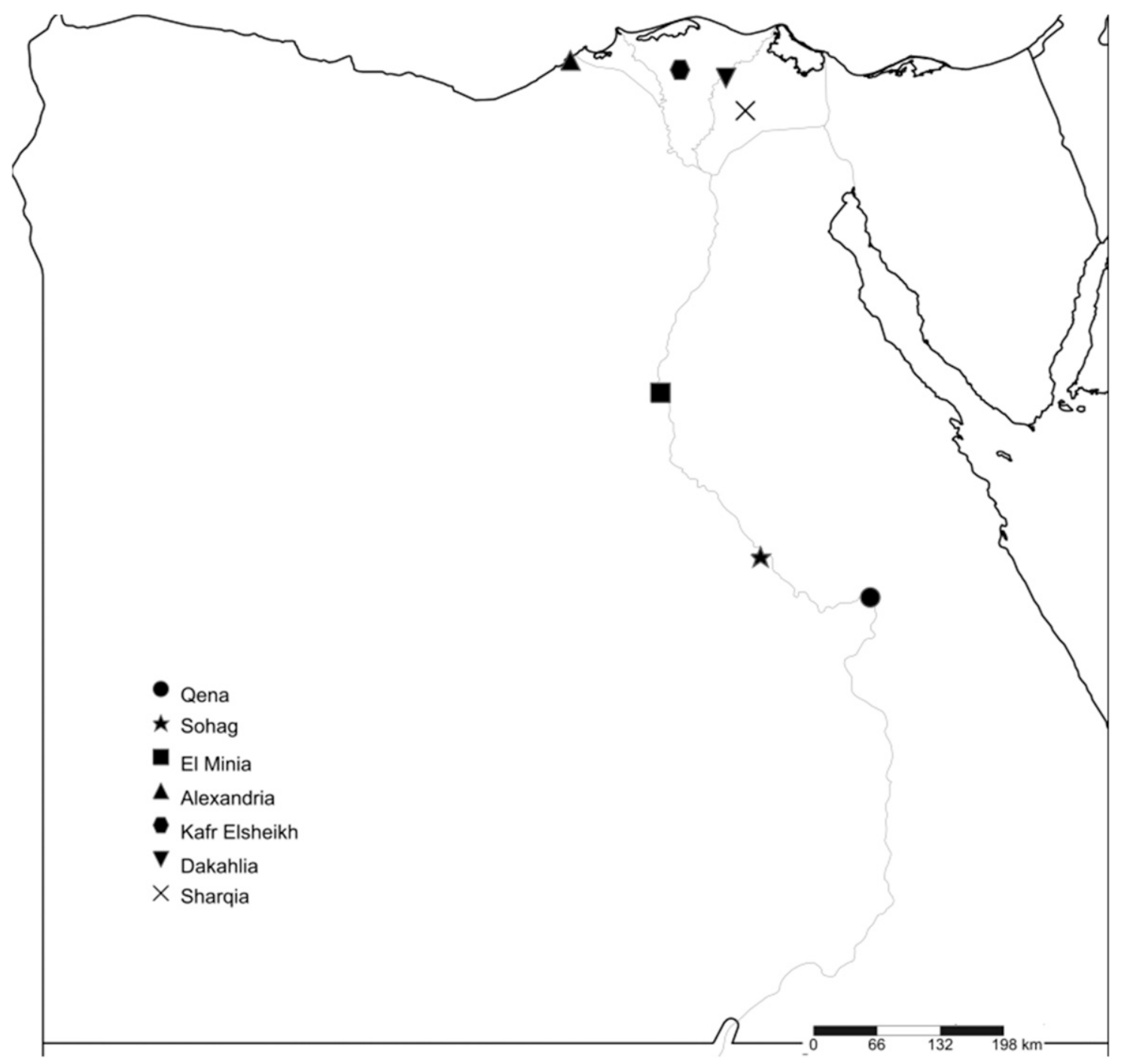

Fig. 1. Provinces where powdery mildew samples were collected from wheat fields in Egypt during the 2015-16 growing season. 
Each isolate was inoculated on two replicate plates of the differentials for a total of four leaf segments per combination of $\mathrm{Pm}$ gene and isolate.

After inoculation, the plates were incubated for 10 days as described above, then rated for powdery mildew infection as by Parks et al. (2008). Disease severity on each leaf segment was rated 10 days postinoculation using the following scale: $0=$ no symptoms, $1=$ faint chlorosis, $2=$ chlorotic lesion, $3=$ necrotic lesion, $4=$ chlorotic lesion with mycelium, $5=$ one or two pustules with conidia, $6=<20 \%$ coverage with pustules, $7=20$ to $50 \%$ coverage with pustules, $8=>50 \%$ coverage with medium to large pustules, and $9=$ approximately $100 \%$ coverage with large pustules. Ratings of 0 to 3 were designated as resistant (R), 4 to 6 as intermediate (I), and 7 to 9 as susceptible (S).

Evaluation of Egyptian cultivars. Fourteen Egyptian bread wheat cultivars and six durum wheat cultivars (Table 2) were challenged with each of the $B$. graminis $\mathrm{f}$. sp. tritici isolates. The pedigrees of the cultivars were previously published (Draz et al. 2015; Emara et al. 2016; Fahmi et al. 2015; Vavilov Research Institute of Plant Industry 2012). The cultivars represented the most widely grown wheat varieties in Egypt.

Detached leaves from 10-day-old seedlings of the 20 cultivars were arranged in a large plate, along with Jagalene as the susceptible control. For replication, all plates contained two detached leaf segments from each cultivar, and each isolate was inoculated on two replicate plates, for a total of four leaf segments per cultivar-isolate combination. The plates were incubated in a growth chamber (approximately $17^{\circ} \mathrm{C}, 12 \mathrm{~h}$ of light) for 10 days, and the cultivars were rated for powdery mildew using the scale described above.

\section{Results}

Virulence of isolates. In all, $10 \mathrm{~B}$. graminis f. sp. tritici isolates were derived from each of the seven Egyptian provinces, for a total of 70 isolates. The responses of each $P m$ gene to the isolates were used to assign the gene to one of three categories, using 0.7 as the minimum proportion of avirulence within a province whereby the gene could be inferred to be effective against that provincial population (Table 3). This level was chosen based on experience in the mid-
Atlantic United States, where wheat powdery mildew epidemics are common and the causal populations have been repeatedly surveyed (Niewoehner and Leath 1998; Parks et al. 2008). Nationally effective Pm genes were considered to be those rated as resistant to at least 7 of the 10 isolates from every Egyptian province. Conversely, nationally ineffective genes were those rated as susceptible in response to at least 7 of the 10 isolates from each province. Regionally effective $P m$ genes were those that were effective in some provinces but not others, using the $70 \%$ standard.

Seven $P m$ genes were nationally effective: $P m 1 b, P m 2, P m 21, P m$ 34, Pm36, Pm37, and Pm53. At the other end of the efficacy spectrum, $P m 6, P m 8$, and $P m 17$ appeared to be defeated throughout the country. The other $P m$ genes varied in their response to particular provincial B. graminis f. sp. tritici populations; for example, $P m l a$ was effective against the El Minia and Alexandria populations but not those from other provinces.

Of the regionally effective genes, the most widely effective, or those with the highest mean percentages of resistant responses, were $P m 3 b$, Pm4b, Pm25, NCA6, and NCAG13 (Table 3). Each of those genes was effective against isolates from all but one or two provinces. Interestingly, with the exception of $P m 4 b$, which appears to be defeated only in El Minia, the other four genes in this category were all ineffective in Sharqia, Dakahlia, or both. Sharqia and Dakahlia are near each other in the north of Egypt (Fig. 1), and this similarity suggests mixing of the B. graminis f. sp. tritici populations in the two provinces.

Resistance of Egyptian wheat cultivars. Fourteen Egyptian bread wheat and six durum wheat cultivars were evaluated against the same set of $70 \mathrm{~B}$. graminis f. sp. tritici isolates collected from seven Egyptian provinces (Table 4). All bread wheat cultivars showed high susceptibility against almost all tested isolates; only cultivar Gemmiza-12 was resistant to half the isolates each from El Minia and Alexandria. This suggested that none of the evaluated bread wheat cultivars had effective $P m$ genes.

Among the six durum wheat cultivars, Beni-Suef-5, Beni-Suef-6, and Beni-Suef-7 showed a high frequency of partial resistance (PR) to $B$. graminis $\mathrm{f}$. sp. tritici isolates collected from the north of Egypt (Alexandria, Kafr Elsheikh, Dakahlia, and Sharqia) (Table 4). The same

Table 1. Powdery mildew differential wheat lines used in virulence analysis of Blumeria graminis f. sp. tritici isolates from Egypt

\begin{tabular}{|c|c|c|c|}
\hline Cultivara & Genes $^{b}$ & Pedigree & Reference \\
\hline CI14114 & Pmla & Axminster/ $8 *$ Chancellor & Sears and Briggle 1969 \\
\hline MocZlatka & $P m 1 b$ & $\begin{array}{l}\text { ATRI-1509-SLK(TR.MO)/(TR.DR)ATRI- } \\
\text { 3310-SLK//*Zlatka[1934] }\end{array}$ & Hsam et al. 1998 \\
\hline CI14118 & $P m 2$ & Ulka/8*Chancellor & McIntosh and Baker 1970 \\
\hline CI14120 & $\operatorname{Pm} 3 a$ & Asosan $/ 8 *$ Chancellor & Briggle and Sears 1966 \\
\hline CI14121 & $P m 3 b$ & Chul//*Chancellor & Briggle and Sears 1966 \\
\hline CI14123 & $\operatorname{Pm} 4 a$ & Khapli/8*Chancellor & Ma et al. 2004 \\
\hline Ronos & $P m 4 b$ & Graf/Kormoran//Kronjuwel & Yi et al. 2008 \\
\hline Coker 747 & Pm6 & Arthur/Coker-68-15 & Helmsjørgensen and Jensen 1973 \\
\hline Kavkaz & $\operatorname{Pm} 8$ & Lutescens $314 \mathrm{H} 147 /$ Bezostaja 1 & Hsam and Zeller 1997 \\
\hline Amigo & Pm17 & $\begin{array}{c}\text { Teewon"S"/6/Gaucho/4/Tascosa/3/Wichita/ } \\
\text { Teewon/5/2*Teewon }\end{array}$ & Heun et al. 1990 \\
\hline $\mathrm{DH} 2$ & $\operatorname{Pm} 21$ & Carries T6VS.6AL from Haynaldia villosa & $\ldots$ \\
\hline NC96BGTA5 & $\operatorname{Pm} 25$ & $\begin{array}{c}\text { Saluda/PI427662 (Triticum monococcum)// } \\
\text { Saluda/3/Saluda }\end{array}$ & Shi et al. 1998 \\
\hline NC96BGTD7 & Pm34 & Saluda *3/TA2492 (Aegilops tauschii) & Miranda et al. 2006 \\
\hline NC96BGTD3 & Pm35 & Saluda $* 3 /$ TA2377 (A. tauschii) & Miranda et al. 2007a \\
\hline 5-BIL29 (durum) & Pm36 & $\begin{array}{c}\text { Latino *5/MG29896 (T. turgidum ssp. } \\
\text { dicoccoides) }\end{array}$ & Blanco et al. 2008 \\
\hline NC99BGTAG11 & $\operatorname{Pm} 37$ & Saluda *3/T. timopheevii accession & Perugini et al. 2008 \\
\hline NC09BGTS16 & Pm53 & Saluda *3/TAU829 (A. speltoides) & Petersen et al. 2015 \\
\hline NC06BGTAG12 & MlAG12 & Saluda $* 3 /$ PI 538457 (T. timopheevii) & Maxwell et al. 2009 \\
\hline NC09BGTUM15 & MlUM15 & Saluda *3/TTCC 223 (A. neglecta) & Worthington et al. 2014 \\
\hline NC96BGTA6 & NCA6 & Saluda $* 3 /$ PI $427772($ T. monococcum $)$ & Miranda et al. 2007b \\
\hline NC06BGTAG13 & NCAG13 & Saluda *3/PI 427442 (T. timopheevii) & Murphy et al. 2007 \\
\hline Jagalene (PI 631376) ${ }^{\mathrm{c}}$ & None & Jagger/Abilene & $\ldots$ \\
\hline
\end{tabular}

a Plant introduction (PI) or cereal investigations (CI) numbers.

${ }^{\mathrm{b}}$ Powdery mildew resistance $(\mathrm{Pm})$ gene or resistance allele.

${ }^{\mathrm{c}}$ Control. 
was true for isolates from Qena province in Upper Egypt, and the three cultivars had somewhat lower PR frequencies to isolates from El Minia and Sohag. In addition, cultivars Sohag-3 and Sohag-5 each showed PR to at least two of the 10 isolates from Qena and Sohag, respectively, while displaying a generally higher frequency of susceptibility to $B$. graminis f. sp. tritici isolates collected from the north of Egypt.

\section{Discussion}

Our study indicates that relatively few $P m$ genes are widely effective against the Egyptian $B$. graminis f. sp. tritici population. Only seven resistance genes (Pm1b, Pm2, Pm21, Pm 34, Pm36, Pm37, and $P m 53$ ) were effective against the population as sampled broadly across Egypt. However, other genes still have efficacy in some regions, and may still be useful when pyramided. This is the first study to determine the response of $P m 1 b, P m 21, P m 34$, and $P m 53$ to the B. graminis f. sp. tritici population in Egypt.

We first discussed the genes that appear to be partially or completely ineffective in Egypt. Pmla was reported as completely ineffective in all sampled locations by El-Shamy et al. (2016) during the 2013-2014 growing season; however, our isolates from previously unsampled regions indicated that Pmla is likely still effective in Alexandria in the north and El Minia in middle Egypt.

High virulence to $P m 3 a$ and $P m 3 b$ had been found in the United States (Niewoehner and Leath 1998; Parks et al. 2008) but low virulence in western Europe (Clarkson and Slater 1999) and Morocco (Imani et al. 2002). For Egypt, we categorized Pm $3 a$ and $P m 3 b$ as regionally effective (Table 3). By contrast, El-Shamy et al. (2016) reported Pm3a as a defeated gene in Egypt; significant virulence was found at only one location (Dakahlia) common to both their study and ours. We found that Pm3a is also likely effective in the other previously unsampled regions of Alexandria, Kafr Elsheikh, El Minia, and Qena, as is $P m 3 b$.

Pm6, $P m 8$, and $P m 17$ were ineffective against Egyptian B. graminis f. sp. tritici isolates in our seedling assay. $P m 6$ and $P m 17$ may express partial resistance in the adult stage (El-Shamy et al. 2016) but Pm8 cannot be recommended as a source of resistance. The similarity in responses of $P m 8$ and $P m 17$ to $B$. graminis f. sp. tritici isolates may be due to their common origin, with both genes originating from rye (Secale cereale) (Niewoehner and Leath 1998). Interestingly, $P m 8$ has lost its efficacy against $B$. graminis f. sp. tritici not only in Egypt but also on the Atlantic coast in Morocco (Imani et al. 2002); in Europe (Hsam and Zeller 2002), including Hungary (Komáromi and Vida 2009); and China (Wang et al. 2005). In the eastern United States, commercial cultivars with $P m 8$ have long been in common use (Niewoehner and Leath 1998); however, the gene began to exhibit breakdown in some regions in 2003 to 2005 (Parks et al. 2008), and was defeated in the Great Plains and all eastern U.S. regions by 2014 (Cowger et al. 2017).

Turning to the genes that appear to be nationally effective in Egypt, we begin with $P m 1 b$. To our knowledge, this was the first time $P m l b$ was tested against Egyptian $B$. graminis f. sp. tritici isolates. Unlike Pmla, to which both our study and the previous one by El-Shamy et al. (2016) recorded widespread virulence, $P m 1 b$ showed high resistance against all the presently tested isolates. $P m 1 b$ is a resistance allele transferred into the common wheat cultivar MocZlatka from Triticum monococcum (Hsam et al. 1998). Due to its efficacy, it is recommended as an effective resistance gene in Egypt.

In Morocco, virulence frequencies to $\mathrm{Pm} 2$ were intermediate (Imani et al. 2002), whereas high virulence to $P m 2$ has been reported in Europe and the eastern United States; and, in Hungary, the frequency of virulence was over $90 \%$ (Komáromi and Vida 2009). By contrast, in the present study, $P m 2$ was effective against most Egyptian isolates. The regional differences are likely due to a relative absence of $P m 2$ in recent Egyptian cultivars and, thus, the lack of selection pressure.

Pm21 has been effective in many parts of the world, including Poland, China, and Europe (Chen et al. 1995; Czembor et al. 2014; Huang et al. 1997; Liu et al. 2015). Transferred to common wheat from Haynaldia (= Dasypyrum) villosum, a wild wheat relative, via a translocation (6VS.6AL), this gene has been widely used in breeding (He et al. 2016) and was recently made accessible to breeders in a spring-habit background (Lukaszewski and Cowger 2017). In our study, $P m 21$ was completely effective against all $B$. graminis f. sp. tritici isolates from Egypt, and it should be useful in common wheat breeding programs there.

Table 2. Egyptian wheat cultivars tested against 70 powdery mildew isolates collected from seven provinces in Egypt

\begin{tabular}{|c|c|c|}
\hline Cultivar & Pedigree & References \\
\hline \multicolumn{3}{|l|}{ Bread wheat } \\
\hline Shandaweel-1 & Site//MO/4/NAC/TH.AC//3*PVN/3/Mirlo/Buc & Draz et al. 2015 \\
\hline Misr-1 & Oasis/Skauz//4*BCN/3/2*Pastor & Draz et al. 2015 \\
\hline Misr-2 & Skauz/BAV92 & Draz et al. 2015 \\
\hline Sids-12 & $\begin{array}{l}\text { BUC//7c/Ald/5/Maya 74/On/1 160.147/3/BB/GLL/4/ } \\
\text { Chat"'S"'/6/Maya/vu1//Cmh 74A.630//4*sx }\end{array}$ & Draz et al. 2015 \\
\hline Sids-13 & Almaz19 = Kauz "S"//TSI/SNB"S" & Draz et al. 2015 \\
\hline Sids-14 & $\begin{array}{l}\text { SW8488*2/Kukuna-CGSS01Y00081T-099M- } \\
\text { 099Y-099M-099B-9Y-0B-0SD }\end{array}$ & Emara et al. 2016 \\
\hline Sakha-93 & Sakha 92/TR 810328 S 8871-1S-2S-1S-0S & Imbaby et al. 2014 \\
\hline Sakha-94 & $\begin{array}{l}\text { Opata/Rayon//Kauz. CMBW90Y3280-0TOPM-3Y- } \\
\text { 010M-010M-010Y-10M-015Y-0Y }\end{array}$ & Draz et al. 2015; Imbaby et al. 2014 \\
\hline Gemmiza-9 & $\begin{array}{l}\text { Ald“S”/Haus//CMH74A.630/SxCGM4583-5GM- } \\
\text { 1GM-0GM }\end{array}$ & Imbaby et al. 2014 \\
\hline Gemmiza-10 & $\begin{array}{l}\text { Maya74“S”/ON/1160-147/3/Bb/G11/4/chat“S”/5/ } \\
\text { crow“S”CGM5820- 3GM-1GM-2GM-0GM }\end{array}$ & Imbaby et al. 2014 \\
\hline Gemmiza-11 & $\begin{array}{l}\text { B0W"S"/KVZ"S"//7C/SERI82/3/Giza168/Sakha61. } \\
\text { GM7892-2GM-1GM-2GM-1GM-0GM }\end{array}$ & Draz et al. 2015 \\
\hline Gemmiza-12 & $\begin{array}{l}\text { OTS/3/Sara/THB//vee-CMss97Y0027S-5Y-010M- } \\
\text { 010Y-010M-2Y-1M-0Y-06M-06M-0GM }\end{array}$ & Emara et al. 2016 \\
\hline Giza-168 & Mil/Buc//Seri CM93046-8M-0Y-0M-2Y-0B & Draz et al. 2015 \\
\hline Giza-171 & Gemmiza-9/Sakha-93 & Emara et al. 2016 \\
\hline \multicolumn{3}{|l|}{ Durum wheat } \\
\hline Beni-Suef-4 & Dipper/Bushen-3 & Draz et al. 2015 \\
\hline Beni-Suef-5 & Dipper-2/Bushen-3 & Fahmi et al. 2015 \\
\hline Beni-Suef-6 & Boomer-21/Busca-3 & $\begin{array}{l}\text { Vavilov Research Institute of Plant Industry } \\
2012\end{array}$ \\
\hline Beni-Suef-7 & In registration process & \\
\hline Sohag-3 & Mexi”S"/Mgha/51792//Durum6 & Fahmi et al. 2015 \\
\hline Sohag-5 & In registration process & $\ldots$ \\
\hline
\end{tabular}


Table 3. Virulence of Blumeria graminis f. sp. tritici isolates collected from seven Egyptian provinces to wheat powdery mildew (Pm) resistance genes ${ }^{\mathrm{a}}$

\begin{tabular}{|c|c|c|c|c|c|c|c|c|c|c|c|c|c|c|c|c|c|c|c|c|c|c|c|c|}
\hline \multirow[b]{3}{*}{ Genes $^{\mathbf{b}}$} & \multicolumn{6}{|c|}{ Upper Egypt } & \multirow{2}{*}{\multicolumn{3}{|c|}{$\begin{array}{c}\begin{array}{c}\text { Middle } \\
\text { Egypt }\end{array} \\
\text { El Minia }\end{array}$}} & \multicolumn{12}{|c|}{ Northern Egypt } & & & \\
\hline & \multicolumn{3}{|c|}{ Qena } & \multicolumn{3}{|c|}{ Sohag } & & & & \multicolumn{3}{|c|}{ Alexandria } & \multicolumn{3}{|c|}{ Kafr Elsheikh } & \multicolumn{3}{|c|}{ Dakahlia } & \multicolumn{3}{|c|}{ Sharqia } & \multicolumn{3}{|c|}{ Mean } \\
\hline & $\mathbf{S}$ & $\mathbf{I}$ & $\mathbf{R}$ & $\mathbf{S}$ & $\mathbf{I}$ & $\mathbf{R}$ & $\mathbf{S}$ & $\mathbf{I}$ & $\mathbf{R}$ & $\mathbf{S}$ & $\mathbf{I}$ & $\mathbf{R}$ & $\mathbf{S}$ & $\mathbf{I}$ & $\mathbf{R}$ & $\mathbf{S}$ & $\mathbf{I}$ & $\mathbf{R}$ & $\mathbf{S}$ & $\mathbf{I}$ & $\mathbf{R}$ & $\mathbf{S}$ & $\mathbf{I}$ & $\mathbf{R}$ \\
\hline \multicolumn{25}{|l|}{ Nat eff } \\
\hline$P m 1 b$ & 3 & 0 & 7 & 2 & 0 & 8 & 0 & 0 & 10 & 0 & 0 & 10 & 0 & 0 & 10 & 0 & 0 & 10 & 0 & 0 & 10 & 0.7 & 0 & 9.3 \\
\hline$P m 2$ & 3 & 0 & 7 & 2 & 0 & 8 & 0 & 0 & 10 & 0 & 0 & 10 & 0 & 0 & 10 & 0 & 0 & 10 & 0 & 1 & 9 & 0.7 & 0.2 & 9.1 \\
\hline $\operatorname{Pm} 21$ & 0 & 0 & 10 & 0 & 0 & 10 & 0 & 0 & 10 & 0 & 0 & 10 & 0 & 0 & 10 & 0 & 0 & 10 & 0 & 0 & 10 & 0.0 & 0.0 & 10.0 \\
\hline$P m 34$ & 1 & 1 & 8 & 1 & 2 & 7 & 0 & 0 & 10 & 0 & 1 & 9 & 0 & 0 & 10 & 1 & 1 & 8 & 1 & 2 & 7 & 0.6 & 1 & 8.4 \\
\hline Pm36 & 0 & 0 & 10 & 0 & 2 & 8 & 0 & 0 & 10 & 0 & 1 & 9 & 0 & 0 & 10 & 0 & 0 & 10 & 0 & 0 & 10 & 0.0 & 0.4 & 9.6 \\
\hline Pm37 & 0 & 0 & 10 & 0 & 2 & 8 & 0 & 0 & 10 & 0 & 0 & 10 & 0 & 0 & 10 & 0 & 3 & 7 & 0 & 1 & 9 & 0.0 & 0.9 & 9.1 \\
\hline Pm53 & 0 & 1 & 9 & 0 & 1 & 9 & 0 & 0 & 10 & 0 & 0 & 10 & 0 & 1 & 9 & 0 & 0 & 10 & 0 & 1 & 9 & 0.0 & 0.6 & 9.4 \\
\hline \multicolumn{25}{|l|}{ Nat inef } \\
\hline Pm6 & 10 & 0 & 0 & 10 & 0 & 0 & 10 & 0 & 0 & 10 & 0 & 0 & 10 & 0 & 0 & 8 & 2 & 0 & 10 & 0 & 0 & 9.7 & 0.3 & 0.0 \\
\hline Pm8 & 10 & 0 & 0 & 10 & 0 & 0 & 7 & 2 & 1 & 6 & 0 & 4 & 10 & 0 & 0 & 10 & 0 & 0 & 10 & 0 & 0 & 9 & 0.3 & 0.7 \\
\hline Pm17 & 9 & 0 & 1 & 7 & 0 & 3 & 10 & 0 & 0 & 7 & 3 & 0 & 9 & 1 & 0 & 10 & 0 & 0 & 9 & 0 & 1 & 8.7 & 0.6 & 0.7 \\
\hline \multicolumn{25}{|l|}{ Reg eff } \\
\hline Pmla & 7 & 0 & 3 & 7 & 0 & 3 & 1 & 0 & 9 & 0 & 0 & 10 & 8 & 0 & 2 & 10 & 0 & 0 & 10 & 0 & 0 & 6.1 & 0 & 3.9 \\
\hline$P m 3 a$ & 2 & 0 & 8 & 7 & 1 & 2 & 0 & 1 & 9 & 0 & 2 & 8 & 1 & 1 & 8 & 5 & 1 & 4 & 6 & 2 & 2 & 3 & 1.1 & 5.9 \\
\hline$P m 3 b$ & 0 & 0 & 10 & 2 & 2 & 6 & 0 & 1 & 9 & 0 & 0 & 10 & 1 & 0 & 9 & 5 & 1 & 4 & 3 & 1 & 6 & 1.6 & 0.7 & 7.7 \\
\hline$P m 4 a$ & 0 & 0 & 10 & 10 & 0 & 0 & 9 & 1 & 0 & 8 & 0 & 2 & 1 & 0 & 9 & 1 & 1 & 8 & 0 & 0 & 10 & 4.1 & 0.3 & 5.6 \\
\hline$P m 4 b$ & 0 & 0 & 10 & 0 & 0 & 10 & 10 & 0 & 0 & 1 & 0 & 9 & 1 & 1 & 8 & 0 & 1 & 9 & 0 & 1 & 9 & 1.7 & 0.4 & 7.9 \\
\hline $\operatorname{Pm} 25$ & 1 & 2 & 7 & 0 & 1 & 9 & 2 & 0 & 8 & 0 & 0 & 10 & 0 & 0 & 10 & 1 & 5 & 4 & 2 & 3 & 5 & 0.9 & 1.6 & 7.5 \\
\hline Pm35 & 3 & 4 & 3 & 1 & 4 & 5 & 8 & 1 & 1 & 1 & 4 & 5 & 1 & 3 & 6 & 0 & 8 & 2 & 1 & 7 & 2 & 2.2 & 4.4 & 3.4 \\
\hline MlAG12 & 1 & 3 & 6 & 0 & 2 & 8 & 0 & 0 & 10 & 0 & 0 & 10 & 0 & 1 & 9 & 3 & 6 & 1 & 4 & 1 & 5 & 1.1 & 1.9 & 7.0 \\
\hline MlUM15 & 7 & 0 & 3 & 7 & 0 & 3 & 1 & 1 & 8 & 0 & 0 & 10 & 8 & 0 & 2 & 10 & 0 & 0 & 10 & 0 & 0 & 6.1 & 0.2 & 3.7 \\
\hline NCA6 & 1 & 0 & 9 & 0 & 3 & 7 & 0 & 0 & 10 & 0 & 0 & 10 & 0 & 0 & 10 & 1 & 2 & 7 & 0 & 4 & 6 & 0.3 & 1.3 & 8.4 \\
\hline NCAG13 & 1 & 1 & 8 & 0 & 3 & 7 & 0 & 0 & 10 & 0 & 0 & 10 & 0 & 1 & 9 & 4 & 1 & 5 & 3 & 4 & 3 & 1.1 & 1.4 & 7.4 \\
\hline Jagalene & 10 & 0 & 0 & 10 & 0 & 0 & 10 & 0 & 0 & 10 & 0 & 0 & 10 & 0 & 0 & 10 & 0 & 0 & 10 & 0 & 0 & 10.0 & 0.0 & 0.0 \\
\hline
\end{tabular}

Table 4. Response of 20 Egyptian wheat cultivars to 70 Egyptian Blumeria graminis f. sp. tritici isolates $^{\mathrm{a}}$

\begin{tabular}{|c|c|c|c|c|c|c|c|c|c|c|c|c|c|c|c|c|c|c|c|c|c|c|c|c|}
\hline \multirow[b]{3}{*}{ Cultivar } & \multicolumn{6}{|c|}{ Upper Egypt } & \multirow{2}{*}{\multicolumn{3}{|c|}{$\begin{array}{c}\begin{array}{c}\text { Middle } \\
\text { Egypt }\end{array} \\
\text { El Minia }\end{array}$}} & \multicolumn{12}{|c|}{ Northern Egypt } & & & \\
\hline & \multicolumn{3}{|c|}{ Qena } & \multicolumn{3}{|c|}{ Sohag } & & & & \multicolumn{3}{|c|}{ Alexandria } & \multicolumn{3}{|c|}{ Kafr Elsheikh } & \multicolumn{3}{|c|}{ Dakahlia } & \multicolumn{3}{|c|}{ Sharqia } & \multicolumn{3}{|c|}{ Mean } \\
\hline & $\mathbf{S}$ & $\mathbf{I}$ & $\mathbf{R}$ & $\mathbf{S}$ & $\mathbf{I}$ & $\mathbf{R}$ & $\mathbf{S}$ & $\mathbf{I}$ & $\overline{\mathbf{R}}$ & $\mathbf{S}$ & $\mathbf{I}$ & $\mathbf{R}$ & $\mathbf{S}$ & $\mathbf{I}$ & $\mathbf{R}$ & $\mathbf{S}$ & $\mathbf{I}$ & $\mathbf{R}$ & $\mathbf{S}$ & I & $\mathbf{R}$ & $\mathbf{S}$ & $\mathbf{I}$ & $\mathbf{R}$ \\
\hline \multicolumn{25}{|l|}{ Bread wheat } \\
\hline Shandaweel-1 & 10 & 0 & 0 & 10 & 0 & 0 & 3 & 1 & 6 & 5 & 0 & 5 & 10 & 0 & 0 & 10 & 0 & 0 & 10 & 0 & 0 & 8.3 & 0.1 & 1.6 \\
\hline Misr-1 & 10 & 0 & 0 & 10 & 0 & 0 & 10 & 0 & 0 & 10 & 0 & 0 & 10 & 0 & 0 & 10 & 0 & 0 & 10 & 0 & 0 & 10.0 & 0.0 & 0.0 \\
\hline Misr-2 & 10 & 0 & 0 & 10 & 0 & 0 & 10 & 0 & 0 & 10 & 0 & 0 & 10 & 0 & 0 & 10 & 0 & 0 & 10 & 0 & 0 & 10.0 & 0.0 & 0.0 \\
\hline Sids-12 & 10 & 0 & 0 & 10 & 0 & 0 & 10 & 0 & 0 & 10 & 0 & 0 & 10 & 0 & 0 & 10 & 0 & 0 & 10 & 0 & 0 & 10.0 & 0.0 & 0.0 \\
\hline Sids-13 & 10 & 0 & 0 & 10 & 0 & 0 & 10 & 0 & 0 & 9 & 1 & 0 & 9 & 1 & 0 & 10 & 0 & 0 & 10 & 0 & 0 & 9.7 & 0.3 & 0.0 \\
\hline Sids-14 & 10 & 0 & 0 & 10 & 0 & 0 & 10 & 0 & 0 & 10 & 0 & 0 & 10 & 0 & 0 & 10 & 0 & 0 & 10 & 0 & 0 & 10.0 & 0.0 & 0.0 \\
\hline Sakha-93 & 10 & 0 & 0 & 10 & 0 & 0 & 10 & 0 & 0 & 10 & 0 & 0 & 10 & 0 & 0 & 10 & 0 & 0 & 10 & 0 & 0 & 10.0 & 0.0 & 0.0 \\
\hline Sakha-94 & 10 & 0 & 0 & 10 & 0 & 0 & 10 & 0 & 0 & 10 & 0 & 0 & 10 & 0 & 0 & 10 & 0 & 0 & 10 & 0 & 0 & 10.0 & 0.0 & 0.0 \\
\hline Gemmiza-9 & 10 & 0 & 0 & 10 & 0 & 0 & 10 & 0 & 0 & 10 & 0 & 0 & 10 & 0 & 0 & 10 & 0 & 0 & 10 & 0 & 0 & 10.0 & 0.0 & 0.0 \\
\hline Gemmiza-10 & 10 & 0 & 0 & 10 & 0 & 0 & 10 & 0 & 0 & 10 & 0 & 0 & 10 & 0 & 0 & 10 & 0 & 0 & 10 & 0 & 0 & 10.0 & 0.0 & 0.0 \\
\hline Gemmiza-11 & 10 & 0 & 0 & 10 & 0 & 0 & 10 & 0 & 0 & 10 & 0 & 0 & 10 & 0 & 0 & 10 & 0 & 0 & 10 & 0 & 0 & 10.0 & 0.0 & 0.0 \\
\hline Gemmiza-12 & 10 & 0 & 0 & 10 & 0 & 0 & 3 & 2 & 5 & 5 & 0 & 5 & 10 & 0 & 0 & 10 & 0 & 0 & 10 & 0 & 0 & 8.3 & 0.3 & 1.4 \\
\hline Giza-168 & 10 & 0 & 0 & 10 & 0 & 0 & 10 & 0 & 0 & 10 & 0 & 0 & 10 & 0 & 0 & 10 & 0 & 0 & 10 & 0 & 0 & 10.0 & 0.0 & 0.0 \\
\hline Giza-171 & 10 & 0 & 0 & 10 & 0 & 0 & 10 & 0 & 0 & 10 & 0 & 0 & 10 & 0 & 0 & 10 & 0 & 0 & 10 & 0 & 0 & 10.0 & 0.0 & 0.0 \\
\hline \multicolumn{25}{|l|}{ Durum wheat } \\
\hline Beni-Suef-4 & 10 & 0 & 0 & 10 & 0 & 0 & 10 & 0 & 0 & 9 & 1 & 0 & 10 & 0 & 0 & 10 & 0 & 0 & 10 & 0 & 0 & 9.9 & 0.1 & 0.0 \\
\hline Beni-Suef-5 & 0 & 7 & 3 & 8 & 2 & 0 & 4 & 6 & 0 & 0 & 8 & 2 & 0 & 6 & 4 & 1 & 9 & 0 & 0 & 9 & 1 & 1.9 & 6.7 & 1.4 \\
\hline Beni-Suef-6 & 0 & 8 & 2 & 8 & 2 & 0 & 6 & 4 & 0 & 1 & 9 & 0 & 0 & 8 & 2 & 0 & 8 & 2 & 0 & 10 & 0 & 2.1 & 7.0 & 0.9 \\
\hline Beni-Suef-7 & 5 & 5 & 0 & 5 & 5 & 0 & 6 & 4 & 0 & 4 & 6 & 0 & 1 & 8 & 1 & 2 & 8 & 0 & 2 & 8 & 0 & 3.6 & 6.3 & 0.1 \\
\hline Sohag-3 & 5 & 5 & 0 & 7 & 3 & 0 & 10 & 0 & 0 & 10 & 0 & 0 & 9 & 1 & 0 & 10 & 0 & 0 & 10 & 0 & 0 & 8.7 & 1.3 & 0.0 \\
\hline Sohag-5 & 8 & 2 & 0 & 8 & 2 & 0 & 10 & 0 & 0 & 9 & 1 & 0 & 9 & 1 & 0 & 7 & 3 & 0 & 9 & 1 & 0 & 8.6 & 1.4 & 0.0 \\
\hline Jagalene & 10 & 0 & 0 & 10 & 0 & 0 & 10 & 0 & 0 & 10 & 0 & 0 & 10 & 0 & 0 & 10 & 0 & 0 & 10 & 0 & 0 & 10.0 & 0.0 & 0.0 \\
\hline
\end{tabular}


Four genes recently introduced into cultivated wheat performed well in response to Egyptian B. graminis f. sp. tritici isolates from all provinces. Pm34 is recommended for pyramiding in U.S. wheat germplasm by Miranda et al. (2006) due to its efficacy against U.S. B. graminis f. sp. tritici isolates. Blanco et al. (2008) transferred Pm36 from T. turgidum var. dicoccoides into durum wheat by backcrossing, and the gene previously performed well against Egyptian powdery mildew (El-Shamy et al. 2016). The efficacy of Pm36 was confirmed in our study, and it can be recommended for both common and durum wheat breeding programs. Pm37 is a dominant gene and mapped on the long arm of chromosome 7A (Perugini et al. 2008); it is highly effective against the U.S. B. graminis f. sp. tritici population. Pm53 was recently mapped to chromosome 5BL and showed good efficacy against powdery mildew from the United States (Petersen et al. 2015).

We found that, in response to the majority of $P m$ genes tested, the provincial samples of $B$. graminis f. sp. tritici varied in frequency of virulence, with some local populations largely virulent to a specific gene while others were largely avirulent. These results indicate that the Egyptian B. graminis f. sp. tritici population is genetically diverse, and suggest that it is locally subdivided. The $P m$ genes that were regionally effective but evoked high avirulence frequencies across the largest number of provinces and, thus, could potentially be useful in breeding, especially in combination, were Pm3b, Pm4b, Pm25, NCA6, MlAG12, and NCAG13.

Our study also indicates that there is little to no major-gene resistance to wheat powdery mildew in existing Egyptian commercial wheat germplasm. This includes Misr-1, Misr-2, and others considered the Egyptian cultivars most resistant to cereal rusts. Pm21, Pm 34, Pm36, Pm37, and Pm53 are promising sources of majorgene resistance that is effective against the Egyptian $B$. graminis $\mathrm{f}$. sp. tritici population and beyond. Egyptian wheat breeding programs should add the introgression of powdery mildew resistance to the set of priority traits, along with rusts and yield quality and quantity, for which new genetic resources are sought. A strategy to introgress and pyramid $\mathrm{Pm}$ genes will be more effective and durable if adult-plant (partial) resistance and quantitatively resistant genetic backgrounds are also utilized. In the United States, several genes confer adultplant (slow-mildewing) resistance, including Pm3e, Pm3f, Pm3g, $P m 4 a, P m 5 b$, and $P m 7$ (C. Cowger, personal observation), and these may also be useful in Egypt.

Although the bread wheat cultivars in this study were uniformly susceptible, some of the Beni-Suef durum cultivars had high levels of intermediate resistance as seedlings, particularly to northern Egyptian $B$. graminis f. sp. tritici populations. That is likely because, in Middle and Upper Egypt, durum is more commonly cultivated than bread wheat, especially the Beni-Suef cultivars, including Beni-Suef-5 and BeniSuef-6. This pattern of cultivation probably selected the pathogen population for full virulence to these cultivars, in contrast to the north, where the pathogen has adapted primarily to bread wheat cultivars.

In conclusion, there is a need to incorporate effective $P m$ genes such as Pm1b, Pm2, Pm21, Pm 34, Pm36, Pm37, and Pm53 into Egyptian bread and durum wheat genotypes. Gene pyramids will be important to guard against rapid defeat of individual genes by $B$. graminis $\mathrm{f}$. sp. tritici evolution. Also, Beni-Suef-5 and -6 likely have effective partial resistance against $\mathrm{Pm}$ isolates from Egypt and are good material for that purpose in durum wheat breeding programs.

\section{Acknowledgments}

We thank the Egyptian Government for funding this project and for its support; M. Abou-Zeid for his help with field sampling of powdery mildew; and T. Cole, M. Hargrove, and R. Whetten for their excellent technical assistance.

\section{Literature Cited}

Abad, A., Lloveras, J., and Michelena, A. 2004. Nitrogen fertilization and foliar urea effects on durum wheat yield and quality and on residual soil nitrate in irrigated Mediterranean conditions. Field Crops Res. 87:257-269.

Akhkha, A., Clarke, D. D., and Dominy, P. J. 2003. Relative tolerances of wild and cultivated barley to infection by Blumeria graminis $\mathrm{f}$. $\mathrm{sp}$. hordei (syn. Erysiphe graminis f. sp. hordei). II-The effects of infection on photosynthesis and respiration. Physiol. Mol. Plant Pathol. 62:347-354.
Blanco, A., Gadaleta, A., Cenci, A., Carluccio, A. V., Abdelbacki, A. M. M., and Simeone, R. 2008. Molecular mapping of the novel powdery mildew resistance gene Pm36 introgressed from Triticum turgidum var. dicoccoides in durum wheat. Theor. Appl. Genet. 117:135.

Briggle, L. W., and Sears, E. R. 1966. Linkage of resistance to Erysiphe graminis f. sp. tritici $(\mathrm{Pm} 3)$ and hairy glume $(\mathrm{Hg})$ on chromosome $1 \mathrm{~A}$ of wheat. Crop Sci. 6: 559-561.

Chen, P. D., Qi, L. L., Zhou, B., Zhang, S. Z., and Liu, D. J. 1995. Development and molecular cytogenetic analysis of wheat-Haynaldia villosa 6VS/6AI. translocation lines specifying resistance to powdery mildew. Theor. Appl. Genet. 91:1125-1128.

Clarkson, J. D. S., and Slater, S. E. 1999. Mildew of wheat. Pages 22-28 in: UK Cereal Pathogen Virulence Survey, 1999 Annual Report. United Kingdom Cereal Pathogen Virulence Survey Committee, Cambridge, England.

Cowger, C., Mehra, L., Arellano, C., Meyers, E., and Murphy, J. P. 2017. Virulence differences in Blumeria graminis f. sp. tritici from the central and eastern United States. Phytopathology doi:10.1094/PHYTO-06-17-0211-R

Czembor, H. J., Domeradzka, O., Czembor, J. H., and Mańkowski, D. R. 2014 Virulence structure of the powdery mildew (Blumeria graminis) population occurring on Triticale ( $\times$ Triticosecale) in Poland. J. Phytopathol. 162:499-512.

Draz, I. S., Mohammed, S. A., Abd-Elmageed, M. K., Omaima, A. A., and Ahmed, F. E. 2015. Screening of wheat genotypes for leaf rust resistance along with grain yield. Ann. Agric. Sci. 60:29-39.

El-Shamy, M. M., Emara, H. M., and Mohamed, M. E. 2016. Virulence analysis of wheat powdery mildew (Blumeria graminis f. sp. tritici) and effective genes in Middle Delta, Egypt. Plant Dis. 100:1927-1930.

El-Shamy, M. M., Sallam, M. E. A., and Awad, H. M. F. 2012. Powdery mildew infection on some Egyptian bread wheat cultivars in relation to environmental conditions. J. Plant Prot. Pathol. Mansoura Univ. 3:363-372.

Emara, H. M., Omar, A. F., El-Shamy, M. M., and Mohamed, M. E. 2016 Identification of Pm24,Pm35 and Pm37 in thirteen Egyptian bread wheat cultivars using SSR markers. Cienc. Agrotec. 40:279-287.

Fahmi, A. I., El-Shehawi, A. M., and El-Orabey, W. M. 2015. Leaf rust resistance and molecular identification of Lr34 gene in Egyptian wheat. J. Microb. Biochem. Technol. 7:338-343.

Götz, M., Friedrich, S., and Boyle, C. 1996. Development of cleistothecia and early ascospore release of Erysiphe graminis DC. f. sp. tritici in winter wheat in relation to host age and climatic conditions. J. Plant Dis. Prot. 103:134-141.

Hao, Y., Parks, R., Cowger, C., Chen, Z., Wang, Y., Bland, D., Murphy, J. P., Guedira, M., Brown-Guedira, G., and Johnson, J. 2015. Molecular characterization of a new powdery mildew resistance gene Pm54 in soft red winter wheat. Theor. Appl. Genet. 128:465-476.

He, H., Zhu, S., Jiang, Z., Ji, Y., Wang, F., Zhao, R., and Bie, T. 2016. Comparative mapping of powdery mildew resistance gene $P m 21$ and functional characterization of resistance-related genes in wheat. Theor. Appl. Genet. 129:819-829.

Helmsjørgensen, J. H., and Jensen, C. J. 1973. Gene Pm6 for resistance to powdery mildew. Euphytica 22:423.

Heun, M., Friebe, B., and Bushuk, W. 1990. Chromosomal location of the powdery mildew resistance gene of Amigo wheat. Phytopathology 80:1129-1133.

Hsam, S. L. K., Huang, X. Q., Ernst, F., Hartl, L., and Zeller, F. J. 1998. Chromosomal location of genes for resistance to powdery mildew in common wheat (Triticum aestivum L. em Thell.). 5. Alleles at the Pml locus. Theor. Appl. Genet. 96: 1129-1134.

Hsam, S. L. K., and Zeller, F. J. 1997. Evidence of allelism between genes Pm8 and Pm17 and chromosomal location of powdery mildew and leaf rust resistance genes in the common wheat cultivar 'Amigo'. Plant Breed. 116:119-122.

Hsam, S. L. K., and Zeller, F. J. 2002. Breeding for powdery mildew resistance in common wheat (Triticum aestivum L.). Pages 219-238 in: The Powdery Mildews: A Comprehensive Treatise. R. R. Belanger, W. R. Bushnell, A. J. Dik, and T. L. W. Carver, eds. American Phytopathological Society Press, St. Paul, MN.

Huang, X. Q., Hsam, S. L. K., and Zeller, F. J. 1997. Identification of powdery mildew resistance genes in common wheat (Triticum aestivum L. em Thell). 9. Cultivars, land races and breeding lines grown in China. Plant Breed. 116:233-238.

Imani, Y., Ouassou, A., and Griffey, C. A. 2002. Virulence of Blumeria graminis f. sp. tritici populations in Morocco. Plant Dis. 86:383-388.

Imbaby, I. A., Mahmoud, M. A., Hassan, M. E. M., and Abd-El-Aziz, A. R. M 2014. Identification of leaf rust resistance genes in selected Egyptian whea cultivars by molecular markers. Sci. World J. 2014: Article ID 574285. doi: $10.1155 / 2014 / 574285$

Jevtic, R., Pribakovic, M., Stojanovic, S., and Leath, S. 1991. Screening the virulence of Erysiphe graminis DC. ex Merat f. sp. tritici Em. Marchal in mobile nurseries. Plant Prot. 42:21-31.

Komáromi, J., and Vida, G. 2009. Effectiveness of designated major powdery mildew resistance genes in various wheat genotypes. Cereal Res. Commun. 37:213-216.

Last, F. T. 1962. Analysis of the effects of Erysiphe graminis DC. on the growth of barley. Ann. Bot. (Lond.) 26:279-289

Leath, S., and Bowen, K. L. 1989. Effects of powdery mildew, triadimenol seed treatment, and triadimefon foliar sprays on yield of winter wheat in North Carolina. Phytopathology 79:152-155.

Leath, S., and Heun, M. 1990. Identification of powdery mildew resistance genes in cultivars of soft red winter wheat. Plant Dis. 74:747-752.

Limpert, E., Felsenstein, F. G., and Andrivon, D. 1987. Analysis of virulence in populations of wheat powdery mildew in Europe. J. Phytopathol. 120:1-8. 
Liu, N., Liu, Z. L., Gong, G., Zhang, M., Wang, X., Zhou, Y., Qi, X., Chen, H., Yang, J., Luo, P., and Yang, C. 2015. Virulence structure of Blumeria graminis f. sp. tritici and its genetic diversity by ISSR and SRAP profiling analyses. PLoS One 10:e130881.

Lukaszewski, A. J., and Cowger, C. 2017. Re-engineering of the Pm21 transfer from Haynaldia villosa to bread wheat by induced homoeologous recombination. Crop Sci. 57:2590-2594.

Ma, Z.-Q., Wei, J.-B., and Chen, S.-H. 2004. PCR-based markers for the powdery mildew resistance gene Pm4a in wheat. Theor. Appl. Genet. 109:140-145.

Maxwell, J. J., Lyerly, J. H., Cowger, C., Marshall, D., Brown-Guedira, G., and Murphy, J. P. 2009. MlAG12: A Triticum timopheevii-derived powdery mildew resistance gene in common wheat on chromosome 7AL. Theor. Appl. Genet. 119:1489-1495.

McIntosh, R. A., and Baker, E. P. 1970. Cytogenetical studies in wheat. IV. Chromosome location and linkage studies involving the Pm2 locus for powdery mildew resistance. Euphytica 19:71-77.

Miranda, L. M., Murphy, J. P., Marshall, D., Cowger, C., and Leath, S. 2007a. Chromosomal location of Pm35, a novel Aegilops tauschii derived powdery mildew resistance gene introgressed into common wheat (Triticum aestivum L.). Theor. Appl. Genet. 114:1451-1456.

Miranda, L. M., Murphy, J. P., Marshall, D., and Leath, S. 2006. Pm34: A new powdery mildew resistance gene transferred from Aegilops tauschii Coss. to common wheat (Triticum aestivum L.). Theor. Appl. Genet. 113:1497-1504.

Miranda, L. M., Perugini, L., Srnić, G., Brown-Guedira, G., Marshall, D., Leath, S., and Murphy, J. P. 2007b. Genetic mapping of a Triticum monococcum-derived powdery mildew resistance gene in common wheat. Crop Sci. 47:2323-2329.

Murphy, J. P., Navarro, R. A., Marshall, D., Cowger, C., Cox, T. S., Kolmer, J. A., Leath, S., and Gaines, C. S. 2007. Registration of NC06BGTAG12 and NC06BGTAG13 powdery mildew-resistant wheat germplasm. J. Plant Regist. 1:75-77.

Niewoehner, A. S., and Leath, S. 1998. Virulence of Blumeria graminis f. sp. tritici on winter wheat in the Eastern United States. Plant Dis. 82:64-68.

Parks, R., Carbone, I., Murphy, J. P., Marshall, D., and Cowger, C. 2008. Virulence structure of the Eastern U.S. wheat powdery mildew population. Plant Dis. 92: 1074-1082.

Perugini, L. D., Murphy, J. P., Marshall, D., and Brown-Guedira, G. 2008. Pm37, a new broadly effective powdery mildew resistance gene from Triticum timopheevii. Theor. Appl. Genet. 116:417-425.

Petersen, S., Lyerly, J. H., Worthington, M. L., Parks, W. R., Cowger, C., Marshall, D. S., Brown-Guedira, G., and Murphy, J. P. 2015. Mapping of powdery mildew resistance gene Pm53 introgressed from Aegilops speltoides into soft red winter wheat. Theor. Appl. Genet. 128:303-312.
Peusha, H., Enno, T., and Priilinn, O. 2000. Chromosomal location of powdery mildew resistance genes and cytogenetic analysis of meiosis in common wheat cultivar Meri. Hereditas 132:29-34.

Rashed, M. A., Atta, A. H., Shehab El-Din, T. M., and Mostafa, A. M. 2016. Development of SSR \& STS molecular markers associated with stem rust resistance in bread wheat (Triticum aestivum 1.). Egypt. J. Genet. Cytol. 45: 261-278.

Sabri, N., Dominy, P. J., and Clarke, D. D. 1997. The relative tolerances of wild and cultivated oats to infection by Erysiphe graminis f. sp. avenae: II. The effects of infection on photosynthesis and respiration. Physiol. Mol. Plant Pathol. 50:321-335.

Sears, E. R., and Briggle, L. W. 1969. Mapping the gene Pml for resistance to Erysiphe graminis f. sp. tritici on chromosome 7A of wheat. Crop Sci. 9:96-97.

Shi, A. N., Leath, S., and Murphy, J. P. 1998. A major gene for powdery mildew resistance transferred to common wheat from wild einkorn wheat. Phytopathology 88:144-147.

Smedegard-Petersen, V. 1967. Studies on Erysiphe graminis DC. with a special view to the importance of the perithecia for attacks on barley and wheat in Denmark. K. Vet. Landbohoejsk. Arsskr. 77:1-28.

Szunics, L., and Szunics, L. 1999. Wheat powdery mildew resistance genes and their application in practice. Acta Agron. Hung. 47:69-89.

Turner, D. M. 1956. Studies on cereal mildew in Britain. Trans. Br. Mycol. Soc. 39:495-506, IN7.

Vavilov Research Institute of Plant Industry. 2012. Genetic Resources Information System for Wheat and Triticale. http://www.wheatpedigree.net/sort/show/111669

Wang, Z. L., Li, L. H., He, Z. H., Duan, X. Y., Zhou, Y. L., Chen, X. M., Lillemo, M., Singh, R. P., Wang, H., and Xia, X. C. 2005. Seedling and adult plant resistance to powdery mildew in Chinese bread wheat cultivars and lines. Plant Dis. 89:457-463.

Worthington, M., Lyerly, J., Petersen, S., Brown-Guedira, G., Marshall, D., Cowger, C., Parks, R., and Murphy, J. P. 2014. MIUM15: An Aegilops neglecta-derived powdery mildew resistance gene in common wheat. Crop Sci. 54:1397-1406.

Yi, Y. J., Liu, H. Y., Huang, X. Q., An, L. Z., Wang, F., and Wang, Z. L. 2008 Development of molecular markers linked to the wheat powdery mildew resistance gene $P m 4 b$ and marker validation for molecular breeding. Plant Breed. 127:116-120.

Zhang, D., Ouyang, S. H., Wang, L. L., Cui, Y., Wu, Q. H., Liang, Y., Wang, Z.Z., Xie, J. Z., Zhang, D. Y., Wang, Y., Chen, Y. X., and Liu, Z. Y. 2015. Comparative genetic mapping revealed powdery mildew resistance gene MIWE4 derived from wild emmer is located in same genomic region of Pm36 and MI3D232 on chromosome 5BL. J. Integr. Agric. 14:603-609. 